\title{
Evaluation of silymarin and / or ginger effect on induced hepatotoxicity by carbon tetrachloride in male albino rats
}

\author{
Hassan H. A.* and EL-Gendy A. M** \\ *Zoology Department, Faculty of Science, Mansoura University, Mansoura, Egypt. \\ **Zoology Department, Faculty of Science (Girls), AL-Azhar Univfersity, Nasr City, \\ Cairo, Egypt.
}

\begin{abstract}
Liver disease appears to be increase. Part of this increase may be due to our frequent contact with chemicals and other environmental pollutants. The amount of medicne consumed has increased greatly which could be danger to the liver.

The hepatoprotective flavonoid, silymarin $(7.56 \mathrm{mg} / \mathrm{Kg}$ b. wt.) and ginger (Zingiber officinale) (1\% of diet) for 4 weeks were used to ameliorate the liver injury in rats intoxicated with carbon tetrachloride $\left(\mathrm{CCL}_{4}\right.$, single acute dose $4 \mathrm{ml} / \mathrm{Kg}$ b. wt. of $50 \% \mathrm{v} / \mathrm{v} \mathrm{CCL}$ in olive oil, subcutaneous).

The obtained results showed that $\mathrm{CCL}_{4}$ decreased serum and liver total protein and albumin. Also reduced glutathione content. The antioxidant enzymes; glutathione-S-transferase, superoxide dismutase and catalase activity decreased in the liver of $\mathrm{CCL}_{4}$ toxicity group. On the other hand, $\mathrm{CCL}_{4}$ toxicity increased serum and liver bilirubin, total lipid and total cholestertol levels. In addition, liver function (aspartate aminotransferase, alanine aminotransferase and alkaline phosphatase) and liver lipid peroxidation content showed significant increase in the $\mathrm{CCL}_{4}$ treated group.

Previous parameters turned back to normal values in carbon tetrachloride intoxicated rats after treating with silymarin and/ or ginger for one month. Meanwhile, the most interesting effect was induced by a combination of silymarin and ginger. Hence, the present findings will provide a potential scope for future use of ginger for the treatment of liver disorders.
\end{abstract}

\section{Key words: Silymarin-ginger-carbon tetracholoride-hepatotoxicity- rats.}

\section{Introduction}

The liver plays an astonishing array of vital functions in the maintenance and performance of the body. Some of these major functions include carbohydrate, protein and fat metabolism, detoxification and secretion of bile. Therfore, the maintenance of healthy liver is vital to overall health and well being (Treadway, 1998 and Aris et al., 2001). Unfortunately, the liver is often abused by environmental toxins, poor eating habits and over the counter drug use, which can damage and weaken the liver and evantually leads to hepatitis, cirrhosis and liver disease. Conventional medicine is now pursuing the use of natural products such as herbs to provide the support that the liver needs on a daily basis.( Treadway, 1998).

Silymarin is the active constituent of Silybum marianum cited as one of the oldest known medicinal plants, since 1970s, silymarin has been used for treatment of liver disease (Giese, 2001) and a dose of $420 \mathrm{mg} /$ day was shown to improve indices of liver function (AST, ALT, GGT and bilirubin) in patients with liver diseases of various aetiology (Wellington and Jarvis, 2001). Silymarin is used for the treatment of several hepatic disorders (Hakova and Misuruva, 1993) and is mainly indicated for acute and chronic hepatitis, liver cirrhosis, fatty degeneration and toxic metabolic liver 
disease (Feher et al., 1987). Silymarin has antioxidant activity (Valenzuela and Garrido, 1994). It inhibited free radical induced lipid peroxidation in microsomal and mitochondrial preparation of human red blood cells, thereby stabilizing the structure of the cell membrane (Koch and Loffler, 1985). Silymarin inhibited hepatotoxicity induced by carbon tetrachloride (Letteron $e t$ al., 1990). Intraperitoneal or intragastric administration of silymarin $(15-800 \mathrm{mg} / \mathrm{Kg}$ body weight) to dogs, mice and rats prevented carbon tetrachloride induced liver damage (Mourelle and Favari, 1989 and Muriel and Mourelle, 1990). This effect of silymarin was attributed to its antioxidant activity, a decrease in the metabolic activation of carbon tetrachloride and stabilization of hepatocyte membranes (Muriel and Mourelle, 1990). Silymarin also increased the redox state and the total glutathione content in the liver, intestine and stomach of rats after intraperitoneal administration $(200 \mathrm{mg} / \mathrm{Kg}$ body weight) (Valenzuela and Garrido, 1994).

Ginger rhizome (Zingiber officinale) is one of the best known spices and it has also been universally used throuhout history for its health benifits.It is used traditionally to promote digestion (Bone, 1997). The dried extract of ginger contains monoterpenes and sesquiterpenes. The main antioxidant active ingradients in ginger are the gingerols and shogaols and some related phenolic ketone derivatives. Ginger extract possesses antioxidative characteristics, since it can scavenge superoxide anion and hydroxyl radicals (Reddy and Lokesh, 1992; Krishnakantha and Lokesh, 1993 and Cao et al., 1993). Gingerol from ginger inhibited, at high concentrations, ascorbate/ ferrous complex induced lipid peroxidation in rat liver microsomes (Reddy and Lokesh, 1992). Furthermore, ginger acts as a hypolipidemic agent in cholesterol fed rabbits (Sharma et al., 1996 and Bhandari et $a l ., 1998)$. Feeding rats ginger significantly elevated the activity of hepatic cholesterol7-hydroxylase, the rate limiting enzyme in bile acids biosynthesis, thereby stimulating cholesterol conversion to bile acids, resulting in elimination of cholesterol from the body (Srinivasan and Sambaiah 1991).
In addition, a pure constituent from ginger [E-8beta, 17 epoxylabd-12-ene-15,16-dial (ZT)], was shown to inhibit cholesterol biosynthesis in homogenated rat liver (Tanabe et al., 1993). Recently, Fuhrman et al. (2000) concluded that consumption of ginger extract may decrease atherosclerosis development, since it is associated with reduced macrophage-mediated oxidation of LDL, reduced uptake of oxidized LDL by macrophages, reduced oxidative state of LDL and reduced LDL aggregation. All these effects lead to a reduced cellular cholesterol accumulation and foam cell formation, the hallmark of early atherosclerosis.

Carbon tetrachloride is a xenoboitic, which produce hepatotoxicity in humans, as well as, in animals (Chenery et al., 1981). The hepatotoxic effect of carbon tetrachloride is known to result from its reductive dehalogenation by the cytochrom $\mathrm{P}_{450}$ enzyme system to the highly reactive free radical, trichloromethyl radical $\mathrm{CCL}_{3}{ }^{-}$ (McCay et al., 1984). This radical quickly adds molecular oxygen to form trichloromethylperoxy radical $\mathrm{CCL}_{3} \mathrm{OO}^{-}$(Letteron et al., 1990). Removal of hydrogen atoms from unsaturated fatty acids by such radicals creates carbon-centered lipid radical (McCay et al., 1984). These later radicals quickly add molecular oxygen to form lipid peroxyl radicals, thereby initiating the process of lipid peroxidation (Letteron et al., 1990). Unless scavenged by radical scavengers, these lipid peroxyl radicals in turn abstract hydrogen atoms from other lipid molecules, thereby propagating the process of lipid peroxidation (Recknagel, 1983).

Therfore, the objective of the present study was to examine the possible curative effect of silymarin and/or ginger in ratinduced hepatotoxicity by carbon tetrachloride. Also, to compare the effectiveness of ginger in relation to silymarin in treating hepatotoxicity.

\section{Materials And Methods}

Thirty male Sprague-Dawley rats (120-140 g), obtained from the Egyptian 
Organization for Biological products and vaccines were used in the present study. Animals were kept under standard conditions throughout the experimental period. The animals were fed on standard diet. Liberal water intakes were available.

Carbon tetrachloride $\left(\mathrm{CCL}_{4}\right)$, Silymarin and Ginger were used for treatment in the present study. Carbon tetrachloride was obtained from ADWIC Co, Egypt and used as 50\% solution in olive oil. Silymarin was purchased from Sedico company (Six-October City, Egypt) in the form of sachets, each sachet contains $140 \mathrm{mg}$. Ginger (Zingiber officinale) powder was obtained from spice shop in Mansoura. Animals were divided into five groups of six rats each as follow:

Group 1: Control group, rats of this group were injected subcutaneously with $4 \mathrm{ml} / \mathrm{Kg}$ b. wt. of olive oil.

Group2: Carbon tetrachloride intoxicated group, rats of this group were injected 4 $\mathrm{ml} / \mathrm{Kg}$ b. wt. subcutaneously by a single dose of $50 \% \mathrm{v} / \mathrm{v}$ of carbon tetrachloride in olive oil (Jayasekhar et al., 1997).

Group3: Carbon tetrachloride intoxicated rats and treated with silymarin. Rats were injected with the same dose of $\mathrm{CCL}_{4}$ as in the second group and simultaneously given daily gavage administration of silymarin at a dose of $7.56 \mathrm{mg} / \mathrm{Kg} \mathrm{b}$. wt. For 4-weeks (Ghosh, 1971).

Group4: Carbon tetrachloride intoxicated rats and treated with ginger. Rats were injected with the same dose of CCL4 as in the second group and administered daily with ginger $(1 \% \mathrm{w} / \mathrm{w}$ in diet) for 4 weeks (Newall et al., 1996).

Group5: Carbon tetrachloride intoxicated rats and treated with both silymarin and ginger. Rats were injected with the same dose of CCL4 as in the second group and simultaneously given silymarin as group (3) and ginger as group (4).

By the end of the experimental period, normal and treated rats were fasted for 12 hours, sacrified and the blood sample were taken and centrifuged at 3000 r.p.m. for 20 minutes. The clear, non-heamolysed supernatent sera were taken and kept at $20^{\circ} \mathrm{C}$ for biochemical analysis. The animals were rapidly dissected and small pieces of liver were removed out and tissue homogenates were prepared in ice cold physiological saline solution and kept at $20{ }^{\circ} \mathrm{C}$ for further analysis.

Stanbio kits (Stanbio Laboratory, INC. 2930 East Houstion Streat San Antonio, Texas, USA) were used for Biochemical investigation. Total protein (TP) was assayed by Biuret reaction according to Doumas (1975). Albumin (A) was estimated by the method of Doumas and Giggs (1972). Total bilirubin was measured according to Jendrassik and Grof (1938) method. Total lipid and total cholesterol were estimated according to the methods described by Knight et al. (1972) and Stein (1986) respectively. Serum and liver activities of aspartate aminotransferase (AST) and alanine aminotransferase (ALT) were carried out by the technique of Reitman and Frankle (1957). Alkaline phosphatase (ALP) activity was estimated according to Teitz (1976) method.

Also thiobarbituric acid reactive substances (TBARS) was determined as descryibed by Esteribauer and Cheesman (1990). Liver content of glutathione (GSH) was estimated by the method of Prins and Loose (1969). The activity of superoxide dismutase (SOD) was assayed according to the method of Niskikimi etal. (1972). Glutathione- S- transferase (GSH-S-T) activity was determined by the method of Habig et al. (1974) and catalase activity was detected by Aebi (1983).

All results were expresed as mean \pm S.E of 6 animals. The obtained data were compared using Student t-test as described by Snedecor and Cochran (1982). The level of significance was expressed as significant at $\mathrm{P}<0.05$. Percent of changes in relation to control and $\mathrm{CCL}_{4}$ intoxicated groups were calculated.

\section{Results}

After one month of a single acute dose of carbon tetrachloride intoxication, rats showed decreases in serum and liver total protein and albumin. On the other hand, improvement of the above mentioned parameters in the serum and liver were 
recorded in $\mathrm{CCL}_{4}$ intoxicated rats treated with silymarin and/or ginger (table $1 \& 2$ ).

As shown in table (1\&2), increased serum and liver total bilirubin, total lipid and total cholesterol were recorded in $\mathrm{CCL}_{4}$ intoxicated rats when compared with control group $(\mathrm{P}<0.05)$. Both silymarin and ginger individually improved in these parameters (bilirubin, total lipid and total cholesterol) in serum and liver. Combination of silymarin and ginger in $\mathrm{CCL}_{4}$ treated rats decreased serum total bilirubin (-13.48 \&-31.86) comparing with control and $\mathrm{CCL}_{4}$ intoxicated group respectively, total lipid (+7.95 \& -22.66) in comparison with control and $\mathrm{CCL}_{4}$ intoxicated groups respectively and total cholesterol (-9.88 \& -38.14) in relation to control and $\mathrm{CCL}_{4}$ intoxicated groups respectively. Liver total bilirubin showed a marked decrease $(-22.57 \&-42.69)$ in $\mathrm{CCL}_{4}$ intoxicated rats treated with silymarin and ginger compared with control and $\mathrm{CCL}_{4}$ treated groups respectively. Also, decreased contents of liver total lipid in $\mathrm{CCL}_{4}$ intoxicated rats treated with silymarin and ginger $(-19.33 \&-23.25)$ was observed when compared with control and $\mathrm{CCL}_{4}$ treated group respectively. Another decreases of liver total cholesterol (-27.98 \&-39.59) were recorded in $\mathrm{CCL}_{4}$ intoxicated rats treated with silymarin and ginger compared with control and $\mathrm{CCL}_{4}$ treated ones respectively.

As shown in table (3), the activities of AST, ALT and ALP in the serum increased significantly in all groups compared to control group, while decreased significantly compared with $\mathrm{CCL}_{4}$ intoxicated group, except serum ALP which decreased significantly in $\mathrm{CCL}_{4}$ intoxicated group treated with both silymarin and ginger (-5.19 \& -26.56) compared with control and $\mathrm{CCL}_{4}$ intoxicated groups respectively.

Activities of AST and ALT also increased in the liver of $\mathrm{CCL}_{4}$ treated group $(+16.49 \&+5.75)$ when compared with control group respectively. Both silymarin and ginger individually decreased liver AST and ALT activities when compared with $\mathrm{CCL}_{4}$ intoxicated group. The recorded liver AST and ALT activities showed significant changes when compared with $\mathrm{CCL}_{4}$ intoxicated rats.

Combination of silymarin and ginger in $\mathrm{CCL}_{4}$ intoxicated rats showed decreased liver activities of AST and ALT which was significant when compared with control and $\mathrm{CCL}_{4}$ intoxicated groups (table 3). On the other hand, Liver ALP decreased significantly in $\mathrm{CCL}_{4}$ intoxicated rats and silymarin treated $\mathrm{CCL}_{4}$ intoxicated group but increased in ginger treated $\mathrm{CCL}_{4}$ intoxicated rats and silymarin plus ginger treated $\mathrm{CCL}_{4}$ intoxicated groups when compared with control group as shown in table (3).

There were an increase in liver lipid peroxidation (TBARS) $(+81.51)$ in $\mathrm{CCL}_{4}$ intoxicated rats compared with control group, however, TBARS decrease significantly in other groups when compared to $\mathrm{CCL}_{4}$ intoxicated group. These decreases still above that of control group, except compination of silymarin and ginger treatment which showed insignificant changes of liver lipid peroxidation in comparison to control group (+3.93) (table 4). Reduced glutathione (GSH) in the liver of CCL4 intoxicated group decreased significantly (-40.39 )in relation to control group, while high liver concentrations of GSH were reported in other treated groups when compared to control group (table 4).

In addition to changes observed in the liver GSH and lipid peroxidation, there were also changes in the activities of glutathione-S-transferase (GSH-S-T), superoxide dismutase (SOD) and catalase enzymes. In $\mathrm{CCL}_{4}$ intoxicated rats and $\mathrm{CCL}_{4}$ intoxicated treated with silymarin, activities of antioxidant enzymes decreased significantly comparing to control group. $\mathrm{CCL}_{4}$ intoxicated rats treated with ginger alone ot combined with silymarin had increased activities of liver enzymes (GSH-S-T, SOD and catalase) when compared with both control and $\mathrm{CCL}_{4}$ intoxicated groups (table 4). 
Table (1): Effect of silymarin and/ or ginger on some serum metabolic parameters in different rat groups.

\begin{tabular}{|c|c|c|c|c|c|}
\hline $\begin{array}{c}\text { Groups } \\
\text { Parameters }\end{array}$ & Control & $\mathrm{CCL}_{4}$ & $\mathrm{CCL}_{4}+$ silymarin & $\mathrm{CCL}_{4}+$ ginger & $\begin{array}{c}\mathrm{CCL}_{4}+\text { silymarine } \\
\text { ginger }\end{array}$ \\
\hline Total protein $(\mathrm{g} / \mathrm{dl})$ & $7.72 \pm 0.26$ & $\begin{array}{c}6.66 \pm 0.19 \\
a \\
-13.73^{\star}\end{array}$ & $\begin{array}{c}7.23 \pm 0.17 \\
b \\
-6.35^{\star} \& \\
+8.56^{\star *}\end{array}$ & $\begin{array}{c}8.54 \pm 0.18 \\
a \& b \\
+10.62^{*} \& \\
+28.23^{\star *}\end{array}$ & $\begin{array}{c}9.02 \pm 0.20 \\
a \& b \\
+16.84^{*} \& \\
+53.44^{* *}\end{array}$ \\
\hline Albumin (g/dl) & $4.80 \pm 0.008$ & $\begin{array}{c}4.04 \pm 0.005 \\
a \\
-15.83^{*}\end{array}$ & $\begin{array}{c}5.32 \pm 0.056 \\
\text { a\&b } \\
+10.83^{\star} \& \\
+31.68^{* *}\end{array}$ & $\begin{array}{c}5.65 \pm 0.084 \\
\text { a\&b } \\
+17.71^{*} \& \\
+39.85^{\star *}\end{array}$ & $\begin{array}{c}6.57 \pm 0.103 \\
\text { a\&b } \\
+36.88^{\star} \& \\
+62.62^{\star *}\end{array}$ \\
\hline Total lipid (mg/dl) & $1012.44 \pm 8.75$ & $\begin{array}{c}1413.26 \pm 8.70 \\
a \\
+39.59^{*}\end{array}$ & $\begin{array}{c}1249.46 \pm 8.16 \\
a \& b \\
+23.41^{*} \& \\
-11.59^{\star *}\end{array}$ & $\begin{array}{c}1201.62 \pm 21.06 \\
a \& b \\
+18.69^{\star} \& \\
-14.98^{\star *}\end{array}$ & $\begin{array}{c}1092.96 \pm 19.01 \\
a \& b \\
+7.95^{\star} \& \\
-22.66^{\star *}\end{array}$ \\
\hline $\begin{array}{l}\text { Total cholesterol } \\
(\mathrm{mg} / \mathrm{dl})\end{array}$ & $262.03 \pm 4.74$ & $\begin{array}{c}381.71 \pm 2.02 \\
\mathrm{a} \\
+45.67^{\star}\end{array}$ & $\begin{array}{c}285.53 \pm 5.6 \\
\text { a\&b } \\
+8.97^{*} \& \\
-25.20^{* \star}\end{array}$ & $\begin{array}{c}256.60 \pm 2.36 \\
b \\
-2.07^{\star} \& \\
-32.78^{\star *}\end{array}$ & $\begin{array}{c}236.14 \pm 4.18 \\
a \& b \\
-9.88^{\star} \& \\
-38.14^{\star *}\end{array}$ \\
\hline Total bilirubin (mg/dl) & $0.178 \pm 0.01$ & $\begin{array}{c}0.226 \pm .004 \\
a \\
+26.97^{\star}\end{array}$ & $\begin{array}{c}0.174 \pm 0.004 \\
b \\
-2.25^{\star} \& \\
-23.01^{* *}\end{array}$ & $\begin{array}{c}0.198 \pm 0.003 \\
a \& b \\
+11.24^{*} \& \\
-12.39^{* *}\end{array}$ & $\begin{array}{c}0.154 \pm 0.004 \\
a \& b \\
-13.48^{\star} \& \\
-31.86^{* *}\end{array}$ \\
\hline
\end{tabular}

All results are expressed as $\mathrm{M} \pm \mathrm{SE}$ of six animals and \% of changes.

$\mathrm{a}=$ significant at $\mathrm{P}<0.05$ when compared with control group.

$\mathrm{b}=$ significant at $\mathrm{P}<0.05$ when compared with $\mathrm{CCL}_{4}$ intoxicated group

$*=\%$ of change in relation to control group.

$* *=\%$ of change in relation to $\mathrm{CCL}_{4}$ intoxicated group

Table (2): Effect of silymarin and/ or ginger on some liver metabolic parameters in different rat groups.

\begin{tabular}{|c|c|c|c|c|c|}
\hline $\begin{array}{c}\text { Groups } \\
\text { Parameters }\end{array}$ & Control & $\mathrm{CCL}_{4}$ & $\mathrm{CCL}_{4}+$ silymarin & $\mathrm{CCL}_{4}+$ ginger & $\begin{array}{c}\mathrm{CCL}_{4}+\text { silymarin }+ \\
\text { ginger }\end{array}$ \\
\hline $\begin{array}{l}\text { Total protein } \\
(\mathrm{g} / 100 \mathrm{~g})\end{array}$ & $30.47 \pm 0.75$ & $\begin{array}{c}24.89 \pm 0.44 \\
a \\
-18.31^{*}\end{array}$ & $\begin{array}{c}29.04 \pm 0.19 \\
b \\
-4.69^{*} \& \\
+16.67^{\star *}\end{array}$ & $\begin{array}{c}29.59 \pm 0.61 \\
b \\
-2.89^{\star} \& \\
+18.88^{* *}\end{array}$ & $\begin{array}{c}34.90 \pm 0.39 \\
a \& b \\
+14.54^{*} \& \\
+40.22^{* *}\end{array}$ \\
\hline Albumin (g/100g) & $7.87 \pm 0.096$ & $\begin{array}{c}6.88 \pm 0.082 \\
a \\
-12.58^{\star}\end{array}$ & $\begin{array}{c}8.40 \pm 0.194 \\
a \& b \\
+6.73^{\star} \& \\
+22.09^{\star \star}\end{array}$ & $\begin{array}{c}8.28 \pm 0.136 \\
a \& b \\
+5.21^{\star} \& \\
+20.35^{\star *}\end{array}$ & $\begin{array}{c}9.65 \pm 0.191 \\
a \& b \\
+22.62^{\star} \& \\
+40.26^{\star \star}\end{array}$ \\
\hline Total lipid (mg/g) & $272.73 \pm 1.17$ & $\begin{array}{c}286.66 \pm 3.75 \\
\mathrm{a} \\
+5.11^{\star}\end{array}$ & $\begin{array}{c}198.92 \pm 3.02 \\
a \& b \\
-27.06^{*} \& \\
-30.61^{* *}\end{array}$ & $\begin{array}{c}236.88 \pm 2.61 \\
a \& b \\
-13.14^{\star} \& \\
-17.37^{\star *}\end{array}$ & $\begin{array}{c}220.0 \pm 3.50 \\
a \& b \\
-19.33^{\star} \& \\
-23.25^{\star *}\end{array}$ \\
\hline $\begin{array}{l}\text { Total cholesterol } \\
(\mathrm{mg} / 100 \mathrm{~g})\end{array}$ & $581.10 \pm 12.55$ & $\begin{array}{c}692.70 \pm 4.60 \\
\mathrm{a} \\
+19.20^{*}\end{array}$ & $\begin{array}{c}492.80 \pm 9.97 \\
a \& b \\
-15.20^{\star} \& \\
-28.86^{\star *}\end{array}$ & $\begin{array}{c}501.16 \pm 4.70 \\
a \& b \\
-13.76^{\star} \& \\
-27.65^{\star *}\end{array}$ & $\begin{array}{c}18.46 \pm 5.77 \\
a \& b \\
-27.98^{\star} \& \\
-39.59^{\star *}\end{array}$ \\
\hline $\begin{array}{l}\text { Total bilirubin } \\
(\mathrm{mg} / 100 \mathrm{~g})\end{array}$ & $66.14 \pm 1.70$ & $\begin{array}{c}89.36 \pm 1.50 \\
a \\
+35.11^{*}\end{array}$ & $\begin{array}{c}68.12 \pm 0.69 \\
b \\
+2.99^{\star} \& \\
-23.77^{\star *}\end{array}$ & $\begin{array}{c}60.60 \pm 0.84 \\
a \& b \\
-8.38^{*} \& \\
-32.18^{\star *}\end{array}$ & $\begin{array}{c}51.21 \pm 0.71 \\
a \& b \\
-22.57^{\star} \& \\
-42.69^{\star *}\end{array}$ \\
\hline
\end{tabular}

All results are expressed as $\mathrm{M} \pm \mathrm{SE}$ of six animals and \% of changes.

$\mathrm{A}=$ significant at $\mathrm{P}<0.05$ when compared with control group.

$\mathrm{b}=$ significant at $\mathrm{P}<0.05$ when compared with $\mathrm{CCL}_{4}$ intoxicated group

$*=\%$ of change in relation to control group.

$* *=\%$ of change in relation to $\mathrm{CCL}_{4}$ intoxicated group. 
Table (3) : Effect of silymarine and/ or ginger on some serum and liver enzyme activities in different rat groups (liver function enzymes).

\begin{tabular}{|c|c|c|c|c|c|c|}
\hline & $\begin{array}{c}\text { Groups } \\
\text { Parameters }\end{array}$ & Control & $\mathrm{CCL}_{4}$ & $\mathrm{CCL}_{4}+$ silymarin & $\mathrm{CCL}_{4}+$ ginger & $\underset{\text { ginger }}{\mathrm{CCL}_{4}+\text { silymarin }}+$ \\
\hline \multirow{3}{*}{ હे } & AST (U/I) & $19.28 \pm 0.33$ & $\begin{array}{c}31.00 \pm 0.71 \\
a \\
+60.79^{\star}\end{array}$ & $\begin{array}{c}27.84 \pm 0.36 \\
a \& b \\
+44.40^{\star} \& \\
-10.19^{\star \star}\end{array}$ & $\begin{array}{c}29.60 \pm 0.23 \\
a \& b \\
+53.53^{\star} \& \\
-4.52^{\star \star}\end{array}$ & $\begin{array}{c}25.48 \pm 0.63 \\
a \& b \\
+32.16^{\star} \& \\
-17.81^{\star \star}\end{array}$ \\
\hline & ALT (U/I) & $11.11 \pm 0.38$ & $\begin{array}{c}17.46 \pm 0.30 \\
a \\
+57.16^{\star}\end{array}$ & $\begin{array}{c}14.36 \pm 0.55 \\
a \& b \\
+29.25^{\star} \& \\
-17.75^{\star *}\end{array}$ & $\begin{array}{c}16.14 \pm 0.24 \\
a \& b \\
+45.27^{\star} \& \\
-7.56^{\star \star}\end{array}$ & $\begin{array}{c}12.44 \pm 1.39 \\
a \& b \\
+11.97^{\star} \& \\
-28.75^{\star \star}\end{array}$ \\
\hline & $\operatorname{ALP}(\mathrm{U} / \mathrm{I})$ & $143.88 \pm 2.28$ & $\begin{array}{c}185.74 \pm 2.05 \\
a \\
+29.09^{\star}\end{array}$ & $\begin{array}{c}168.42 \pm 1.09 \\
a \& b \\
+7.32^{\star} \& \\
-9.32^{\star *}\end{array}$ & $\begin{array}{c}157.28 \pm 2.9 \\
a \& b \\
+9.31^{\star} \& \\
-15.32^{\star *}\end{array}$ & $\begin{array}{c}136.41 \pm 1.99 \\
a \& b \\
-5.19^{*} \& \\
-26.56^{\star *}\end{array}$ \\
\hline \multirow{3}{*}{ 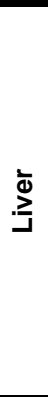 } & AST (U/g) & $169.39 \pm 2.36$ & $\begin{array}{c}197.32 \\
a \\
+16.49^{\star}\end{array}$ & $\begin{array}{c}173.40 \pm 3.12 \\
b \\
+2.37^{\star} \& \\
-12.12^{\star \star} \\
\end{array}$ & $\begin{array}{c}165.40 \pm 2.37 \\
b \\
-2.36^{\star} \\
-16.18^{\star \star} \\
\end{array}$ & $\begin{array}{c}154.35 \pm 1.87 \\
a \& b \\
-8.88^{\star} \& \\
-21.78^{\star *}\end{array}$ \\
\hline & ALT (U/g) & $179.84 \pm 1.87$ & $\begin{array}{c}190.18 \pm 0.76 \\
a \\
+5.75^{\star}\end{array}$ & $\begin{array}{c}177.06 \pm 1.73 \\
\text { b } \\
-1.55^{\star} \& \\
-6.90^{\star *} \\
\end{array}$ & $\begin{array}{c}171.66 \pm 2.16 \\
a \& b \\
-4.55^{\star} \& \\
-9.74^{\star \star} \\
\end{array}$ & $\begin{array}{c}167.20 \pm 1.63 \\
a \& b \\
-7.03^{*} \& \\
-12.08^{\star *} \\
\end{array}$ \\
\hline & $\operatorname{ALP}(U / g)$ & $305.70 \pm 4.55$ & $\begin{array}{c}282.09 \pm 3.34 \\
a \\
-7.72^{\star}\end{array}$ & $\begin{array}{c}284.37 \pm 3.39 \\
a \\
-6.98^{\star} \& \\
+0.81^{\star *}\end{array}$ & $\begin{array}{c}334.42 \pm 5.99 \\
\text { a\&b } \\
+9.39^{\star} \& \\
+18.55^{\star *}\end{array}$ & $\begin{array}{c}385.11 \pm 2.36 \\
a \& b \\
+25.98^{\star} \& \\
+36.52^{\star \star}\end{array}$ \\
\hline
\end{tabular}

All results are expressed as $\mathrm{M} \pm \mathrm{SE}$ of six animals and \% of changes.

$\mathrm{a}=$ significant at $\mathrm{P}<0.05$ when compared with control group.

$\mathrm{b}=$ significant at $\mathrm{P}<0.05$ when compared with $\mathrm{CCL}_{4}$ intoxicated group.

$*=\%$ of change in relation to control group.

$* *=\%$ of change in relation to $\mathrm{CCL}_{4}$ intoxicated group.

Table (4): Effect of silymarin and /or ginger on liver lipid peroxides (TBARS ) and some liver antioxidant parameters in different rat groups

\begin{tabular}{|c|c|c|c|c|c|}
\hline $\begin{array}{l}\text { Groups } \\
\text { Parameters }\end{array}$ & Control & $\mathrm{CCL}_{4}$ & $\begin{array}{l}\mathrm{CCL}_{4}+ \\
\text { silymarin }\end{array}$ & $\mathrm{CCL}_{4}+$ ginger & $\begin{array}{c}\mathrm{CCL}_{4+} \\
\text { silymarin } \\
\text { ginger }\end{array}$ \\
\hline $\begin{array}{c}\text { TBARS } \\
\text { (n.mol/g wet tissue) }\end{array}$ & $38.93 \pm 0.96$ & $\begin{array}{c}70.66 \pm 1.77 \\
a \\
+81.51^{\star}\end{array}$ & $\begin{array}{c}51.75 \pm 2.32 \\
a \& b \\
+32.93^{\star} \& \\
-26.76^{\star \star}\end{array}$ & $\begin{array}{c}47.21 \pm 2.21 \\
a \& b \\
+21.27^{\star} \& \\
-33.19^{\star \star}\end{array}$ & $\begin{array}{c}40.46 \pm 0.88 \\
b \\
+3.93^{\star} \& \\
-42.74^{\star \star}\end{array}$ \\
\hline $\begin{array}{c}\text { GSH } \\
\text { (mg/g wet tissue) }\end{array}$ & $9.16 \pm 0.37$ & $\begin{array}{c}5.46 \pm 0.32 \\
a \\
-40.39^{\star}\end{array}$ & $\begin{array}{c}10.88 \pm 0.14 \\
a \& b \\
+18.78^{\star} \& \\
+99.27^{\star *}\end{array}$ & $\begin{array}{c}17.46 \pm 0.29 \\
a \& b \\
+90.61^{\star} \& \\
+219.78^{\star \star}\end{array}$ & $\begin{array}{c}20.01 \pm 0.46 \\
a \& b \\
+118.45^{\star} \& \\
+266.48^{\star \star}\end{array}$ \\
\hline SOD (U/g wet tissue) & $48.14 \pm 0.99$ & $\begin{array}{c}33.50 \pm 0.99 \\
a \\
-30.41^{\star}\end{array}$ & $\begin{array}{c}35.58 \pm 1.24 \\
a \\
-26.09^{\star} \& \\
+6.21^{\star \star}\end{array}$ & $\begin{array}{c}40.18 \pm 1.16 \\
a \& b \\
-16.54^{\star} \& \\
+19.94^{\star \star}\end{array}$ & $\begin{array}{c}48.06 \pm 1.74 \\
b \\
-0.17^{\star} \& \\
+43.46^{\star \star}\end{array}$ \\
\hline $\begin{array}{c}\text { GSH-S-T } \\
(\mu \mathrm{mol} / \mathrm{min} / \mathrm{g})\end{array}$ & $20.42 \pm 0.52$ & $\begin{array}{c}12.92 \pm 0.37 \\
a \\
-36.73^{\star}\end{array}$ & $\begin{array}{c}14.78 \pm 0.38 \\
a \& b \\
-27.62^{\star} \& \\
+14.40^{\star \star}\end{array}$ & $\begin{array}{c}24.28 \pm 0.40 \\
a \& b \\
+18.90^{\star} \& \\
+87.93^{\star \star}\end{array}$ & $\begin{array}{c}25.52 \pm 0.55 \\
a \& b \\
+24.98^{\star} \& \\
+97.52^{\star \star}\end{array}$ \\
\hline $\begin{array}{c}\text { Catalase } \\
\text { (KU/sec/g wet tissue) }\end{array}$ & $7.46 \pm 0.23$ & $\begin{array}{c}5.57 \pm 0.24 \\
a \\
-25.34^{\star}\end{array}$ & $\begin{array}{c}5.94 \pm 0.18 \\
a \\
-20.38^{\star} \& \\
+6.64^{\star \star}\end{array}$ & $\begin{array}{c}7.70 \pm 0.19 \\
b \\
+3.22^{\star} \& \\
+38.24^{\star *}\end{array}$ & $\begin{array}{c}9.67 \pm 0.52 \\
a \& b \\
+29.62^{\star} \& \\
+73.61^{\star \star}\end{array}$ \\
\hline
\end{tabular}

All results are expressed as $\mathrm{M} \pm \mathrm{SE}$ of six animals and \% of changes.

$\mathrm{a}=$ significant at $\mathrm{P}<0.05$ when compared with control group.

$\mathrm{b}=$ significant at $\mathrm{P}<0.05$ when compared with $\mathrm{CCL}_{4}$ intoxicated group.

$*=\%$ of change in relation to control group.

$* *=\%$ of change in relation to $\mathrm{CCL}_{4}$ intoxicated group. 


\section{Discussion}

The hepatotoxicity of halogenated hydrocarbons, particularly $\mathrm{CCL}_{4}$, has been the subject of numerous investigations in experimental animals (Recknagel and Glende, 1973; Dashti et al., 1989; Klatskin and Conn, 1993; Amer and selim, 2002 and Amer, 2003).

Carbon tetrachloride is an occupational chemical agent widely used as a solvent in insecticide industry and is correlated with high incidence of cetrtain types of cancer (Petrelli et al., 1993). Previous observations demonistrated that pretreatment with different herbal extracts provide various levels of protection against the hepatocellular damage resulting from administration of $\mathrm{CCL}_{4}$ (Johnston and Kroening, 1998 and Amer, 2003).

Since liver injury is used to occure in human without pretreatment with protective medicine, this study was carried out to evaluate the possible use of ginger alone or combined with silymarin in already $\mathrm{CCL}_{4}{ }^{-}$ induced hepatotoxicity in rats.

The present study revealed that acute $\mathrm{CCL}_{4}$ intoxication resulted in a decrease in serum and liver total protein and albumin contents. Similar findings were recorded in liver diseases (Tanaka et al.,1998). Sherlock and Dooley (1993) reported that albumin is the most abundant plasma protein produced by hepatocytes, its depreciation usually reflects decreased hepatic synthesis. This fall is often attributed to hepatic impairment of albumin synthesis. The decrease may also be due to leakage in kidney function leading to the release of albumin with the urine. As well as significant increases in the activities of serum and liver transaminase enzymes (AST and ALT) were noticed. These effects may reflect the hepatocellular damage. Scherlock and Dooley (1993) reported that also the activity of plasma AST and ALT are standard tests for hepatocellular integrity. These measurements assess leakage of hepatic enzymes into the blood stream. The obtained results support the findings of Naziroglu et al. (1999); Ahmed et al. (2000) and Amer (2003). They observed similar effect of $\mathrm{CCL}_{4}$ on the same and other hepatic related parameters after $\mathrm{CCL}_{4}$ intoxication in different animals.
Treatment of $\mathrm{CCL}_{4}$ intoxicated rats with silymarin or ginger improved these parameters (total protein, albumin ,AST and ALP) in the serum and liver indicating amelioration of hepatotoxic effect of $\mathrm{CCL}_{4}$. Furthermore, the combination of silymarin and ginger treatment in $\mathrm{CCL}_{4}$ intoxicated rats increased serum and liver total protein and albumin contents. Hepatoprotective activity of silymarin was reported by and Bean (2002) in patients with alcoholinduced cirrhosis. Also, an improvement of liver function was noticed in patients exposed to toluene and/or xylene vapours for 5-20 years after treatment with silymarin (Szilard et al., 1988). Ginger treatment individually or combined with silymarin improved liver function by decreasing the activities of AST and ALT and increasing serum and liver total protein and albumin contents. These results reflect the effectiveness of ginger in improving hepatic injury induced by $\mathrm{CCL}_{4}$.

Alkaline phosphatase (ALP) is mainly involved in metabolite transport across cell membranes found in a decreasing order of abundance in placenta, ileal, mucosa, kidney, bone and liver (Fishman, 1990). The level of serum ALP is associated mainly with cholestasis, bile salts and to a less extent with liver cell damage (Kaplan, 1972 and Moss, 1997). Carbon tetrachloride intoxicated rats showed elevated serum ALP but decreased liver ALP, which confirm the linkage of this enzyme impairment. Disorders of serum and liver ALP were improved after using silymarin and/or ginger in $\mathrm{CCL}_{4}$ intoxicated rats. This improvement of ALP may reflect liver repair of these groups.

Elevated serum and liver total bilirubin was noticed in $\mathrm{CCL}_{4}$ intoxicated group. Similar increase in serum total and direct bilirubin was seen in patients having cirrhosis, which may reflect abnormal conjugation of bilirubin by the liver due to generalized hepatocellular damage (El-sherbiny et al., 2003). Serum and liver total bilirubin were decreased in $\mathrm{CCL}_{4}$ intoxicated rats after treatment with silymarin or ginger. Combination of both silymarin and ginger recorded more decree- 
ase in serum and liver total bilirubin which becam below the normal value. The obtained results were confirmed by Feher et al. (1987) who reported that silymarin is known to have a reduction effect on total bilirubin in different liver diseases. Similar effect of ginger may indicate the effectiveness of ginger in normal functional status of the liver.

Hyperlipidemic effect of $\mathrm{CCL}_{4}$ was noticed in the serum and liver of $\mathrm{CCL}_{4}$ intoxicated group, might suggest enhanced lipogenesis. Since total lipid and total cholesterol were increased significantly. The observed hyperlipidemia might reflect the impairment of liver cells to metabolize lipids and reduced transformation of cholesterol to bile acid and excretion. In the present study, silymarin and/or ginger reduced serum and liver total lipid and total cholesterol. These results are in agreement with Sharma et al. (1996) and Bhandari et al. (1998) who reported that ginger acts as a hypolipidemic agent in cholesterol fed rabbits. Also, feeding rats ginger significantly elevated the activity of hepatic cholesterol-7-hydroxylase, the rate limiting enzyme in bile acid synthesis, thereby stimulating cholesterol conversion to bile acids, resulting in elimination of cholesterol from the body (Srinivasan and Sambarah, 1991). In addition, pure constituent from ginger [E-8 beta, 17 epoxylabol-12-ene 15,16- dial (ZT)] was shown to inhibit cholesterol biosynthesis in homogenated rat liver (Tanabe et al., 1993). Also, Fuhrman et al. (2000) observed that cholesterol synthesis was inhibited by some ginger extract derived metabolite or by secondary mediator.

The present work also showed an increase in lipid peroxidation after $\mathrm{CCL}_{4}$ intoxication as evidenced by the increased TBARS in the liver. This observation is confirmed by other studies (Riely et al., 1974; Bechtold et al., 1982; Ohta et al., 2000 and Amer, 2003). They concluded the ability of $\mathrm{CCL}_{4}$ to induce lipid peroxidation of liver membrane lipids in rodents. Rapid, extensive lipid peroxidation of the membrane structural lipid has been proposed as the basis of $\mathrm{CCL}_{4}$ hepatotoxicity ( Recknagel and Glende, 1973). A correlation between the metabolism of
$\mathrm{CCL}_{4}$, lipid peroxidation and hepatocyte damage provides the strongest supporting evidence. Both $\mathrm{CCL}_{4}$-induced lipid peroxid-ation and $\mathrm{CCL}_{4}$ toxicity are dependent on reduvtive metabolism by microsomal mixed function oxidase with the generation of trichloromethyl radical (Castro et al., 1972), $\mathrm{CCL}_{3}{ }^{-}$and $\mathrm{CCL}_{3} \mathrm{OO}^{-}$, with ox-radical which arises from the reaction of $\mathrm{CCL}_{3}$ with oxygen, are capable of initiating lipid pero-xidation by abstracting hydrogen from a polyunsaturated fatty acid (Castro et al., 1972 and Packer et al., 1978). Thus while $\mathrm{CCL}_{4}$ causes free radical induced oxidative damage to cells and causes lipid peroxidation, these processes may be parallel responses to the generation of free radicals. Under some condition, lipid peroxidation may determine the extent of injury by amplifying the injury through propagation of free radical processes, generating toxic compounds and impairing detoxication systems (Tribble et al., 1987).

Impairing detoxication systems was seen in $\mathrm{CCL}_{4}$ intoxicated group, since liver GSH content and antioxidant enzymes (GST, SOD and catalase) activities were reduced. Similar results were obtained by Lii et al. (1998) and Amer (2003), they detected a significant decrease in liver GSH content after CCL4 intoxication. Since reduced glutathione (GSH) is an important constitu-ent of cellular protective mechanisms against a number of toxic stimuli including oxygen derived free radicals (Cembalos-Picot et al., 1996). The observed decrease in GSH level in the hepatotoxicated animals might have been due to an increased scavenging of reactive substances that were produced as a result of the necrotic and/or steatic state of the hepatocytes and/ or possible decreased hepatic production of GSH (Lii et al., 1998)

Administration of silymarin and/ or ginger for one month significantly lowerd the lipid peroxidation level induced by $\mathrm{CCL}_{4}$. Furthermore, our study have shown that the supplementation of silymarin and/or ginger regulate the lipid peroxidation by altering the liver GSH and antioxidant enzymes activities. Antioxidant activity of silymarin was reported by Muriel and Mourelle (1990) and Feher and Lang 
(1988), as well as, anti-lipid peroxidation (Basaga et al., 1997) and enhanced detoxification (Baer-Dubowska et al., 1998) were recorded. The hepatoprotective effect of silymarin based on free radical scavinging activity (Abd-Allah et al., 2003). Ginger, also possesses antioxidative charecteristics, since it can scavenge superoxide anion and hydroxyl radicals (Reddy and Lokash, 1992 and Cao et al., 1993). Also, antioxidative effect and free radical scavenging capacity of ginger were detected by Fuhrman et al. (2000). However, tretment with ginger alone or combined with silymarin significantly maintained the level of GSH and antioxidant enzymes activities nearly close the control value. The increased levels of GSH after ginger alone or combined with silymarin treatment may be attributed to an increased rate of GSH synthesis or due to increased hepatic tissue uptake of extracellular GSH. In this connection, GSH has been shown to be mobilized from blood and other tissues to protect target organs in conditions associated with increased oxidative stress (An-Sik et al., 1982 and Lii et al., 1998).

In conclusion, the results of the present study confirm the curative effect of ginger against $\mathrm{CCL}_{4}$ induced hepatotoxicity in rats. The potency of ginger compares well with silymarin. Moreover, combination of ginger and silymarin is more effective. These encouraging results may have future clinical importance because of the increased use of natural herbs by the general population.

\section{Refrences}

1. Abd-Allah, G. A.; El-Sherbiny, E. A. and Goneim, S. T. (2003): The biochemical response to different treatments for chronic liver diseases in HCV carriers. J. Egypt. Ger. Soc. Zool., Comparative Physiology 40A: 121-144.

2. Aebi, HE. (1983): Catalase ed HV. Bergmeyer in. Method of enzymatic analysis vol. 3, Berlin: Verlag Chemie. P. 273-286.

3. Ahmed, S.; Rahman, A.; Alam, A.; Saleem, M.; Athar, M. and Sultana, S. (2000): Evaluation of the efficacy of Lawsonia alba in the alleviation of carbon tetrachloride-induced oxidative stress. J. Ethnopharmacol., 69: 157-164.

4. Amer, F. I. And Selim, M. E. (2002): Protective effects of vitamin $\mathrm{E}$ and/or cimetidine against carbon tetrachlorideinduced hepatotoxicity in male albino rats. Egypt. J. Zool., 38: 107-127.

5. Amer, M. A. (2003): The efficacy of Ginkgo Biloba extract in ameliorating carbon tetrachloride-induced acute hepatic toxicity in adult male albino rats. J. Egypt Ger. Soc. Zool. Comparative physiology, 40(A): $185-200$.

6. An-Sik, C.; Mahin D. M. and AnnReynolds, W. (1982): Inhibition of the enzymes of glutathione metabolism by mercuric chloride in the rat kidney: Reversal by selenium. Biochem. Pharmacol., 31(19):3093-3100.

7. Baer-Dubowska, W.; Szaefer, H. and Krajka-Kuzniak, V. (1998): Inhibition of murine hepatic cytochrome P450 activities by natural and synthetic phenolic compounds. Xenobiotica, 28: 735-743.

8. Basaga, H.; Poli, G.; Tekkaya, C.and Aras, L. (1997) : Free radical scavenging and antioxidative properties of silibin complexes on microsomal lipid peroxidation. Cell Biochem. Funct., 15: 27-33.

9. Bean, P. (2002): The use of alternative medicine in the treatment of hepatitis $\mathrm{C}$. Am. Clin. Lab., 21: 19-21.

10. Bechtold, M.M.; Gee, D. L.; Bruenner, U. and Tappel, A. L. (1982): Carbon tetrachloride-mediated expiration of pentane and chloroform by the intact rat: the effects of pre-treatment with diethylmaleate, SKF525A and Phenobarbital. Toxicol. Lett., 11: 165.

11. Bhandari, U.; Sharma, J. N. and Zafar, R. (1998): The protective action of ethanolic ginger (Zingiber Officinal) extract in cholesterol fed rabbits. J. Ethnopharmacol, 61: 167-171.

12. Bone, K. (1997): Ginger. Brit. J. Phytother., 4(3): 110-120.

13. Cao, Z. F.; Chen, Z. G.; Guo, P.; Zhang, S. M.; Lian, L.X.; Luo, L. and Hu, W. M. (1993): Scavenging effects of ginger on superoxide dismutase anion and hydroxyl radical. Chung-Kuo Chung Yao Tsa Chib, 18: 750-764.

14. Castro,JA.;DiazGomes,MI. and Ferreyra, EC. (1972): Carbon tetyrachlor-ide effect on rat liver and adrenals related to their mixed-function oxygenase content. Biochem. Biophys. Res. Commun., 47: 315-321.

15. Ceballos-Picot, T. ; Iwitkosarsat, V.; Meradboudia, a.; Mnguyen, T.; 
Thevenin, M. ; Jaudon, M. C. ; Zingraff, J. ; Verger, C. ; Jungers, P. and Descampslatscha, B. (1996): Glutathione antioxidant system as a marker of oxidative stress in chronic renal failure. Free Radical Biol. Med., 21: 845-853.

16. Chenery, R. ; George, M. and Krishna, G. (1981): The effect of ionophore A23187 and calcium on $\mathrm{CCL}_{4}$-induced toxicity in cultured rat hepatocytes. Toxicol. Appl. Pharmacol., 60: 241-252.

17. Dashti, M.; Jeppson, B.; Hagerstand, I.; Hultberg, B.; Srinivas, U.; Abdulla, M. and Beng Marks, S. (1989): The aceamide and carbon tetrachloride induced liver cirrhosis. J. Surg. Res., 21 : 83-91.

18. Doumas, B. T. (1975): Colorimetric determination of total protein based on the Biuret method. Clin. Chem. 21: 1159-1166.

19. Doumas, B. T. and Giggs, H. G. (1972): Standard methods of clinical chemistry, Vol. 7; Academic Press New York.

20. El-Sherbiny, E. A. ; Abd-Allah, G. A. and Goneim S. T. (2003): Reletionship of liver function tests to different stages of chronic liver diseases in HCV carriers. J. Egypt. Ger. Soc. Zool., Comparative Physiology, 40A: 71-93.

21. Esteribauer, H. and Cheeseman, K. (1990): Determination of aldehdic lipid peroxidation products: Malonaldehyde and 4- hydroxyonenal., Enzymol.; 186: 407-421.

22. Feher, J. and Lang (1988): Wirkmechanismen der sogenannten leberschutzmittel. Bayer Internist, 4: 3-7.

23. Feher, J.; Cornides, A. and Csomos, G. (1987): Antioxidant and immunomodulant effect of hepatoprotective drugs. In: "Assessment and management of hepatobiliary diseases" Okolicsanyi, L.; Csomon, G. and Crepaldi G. (eds), Springer-Verlag Berlin, Heidelberg, P: 257-263.

24. Fishman, W. H. (1990): Alkaline phosphatase isoenzymes: recent progress. Clin. Biochem., 23: 99-104.

25. Fuhrman, B.; Rosenblat, M.; Hayek, T.; Coleman, R. and Aviram, M. (2000): Ginger extract consumption reduces plasma cholesterol, inhibits LDL oxidation and attenuates development of atherosclerosis in atherosclerotic apolipoprotein E-deficient mice. J. of Nutr. 130: 1124-1131.

26. Ghosh, M. N. (1971): Fundamentals of experimental pharmacology. Academic Press-New York. P. 85.

27. Giese, L. A. (2001): Milk thistle and the treatment of hepatitis. Gastroentrol Nurs., 24: $95-97$
28. Habig, H.; Pabst, J. and Jakoby (1974): Glutathione-S- transferase. The first enzymes step in mercapturic and formation. J. Bio. Chem. 249: 7130-7139.

29. Hakova, H. and Misurova, E. (1993): The effect of silymarine and gamma radiation on nucleic acids in rat organs. J. Pharmacol., 45: 910-912.

30. Jayasekhar, P.; Mohanan, P. V. and Rathinam, K. (1997): Hepatoprotectictive activity of ethyl acetate extract of Acacia catechu. Indian J. of Pharmacology, 29: 426-428.

31. Jendrassik, L. and Grof, P. (1938): Estimation of total bilirubin by diazotized sulfanilic acid and cafeine Biochem. Z., 297: 81-89.

32. Johnston, D. E. and Kroening, C. (1998): Mechanism of early carbon tetrachloride toxicity in cultured rat hepatocytes. Pharmacol. Toxicol., 83: 231-239.

33. Kaplan, M. M. (1972): Alkaline phosphatase. Gastroenterology, 62: 452.

34. Klatskin, G. and Conn, H. (1993): Histopathology of the liver. Vol. 1, Oxford Univ. Press, Oxford and New York.

35. Knight, J. A.; Anderson, S. and James, M. R. (1972): Chemical basis of the sulhophosphovanillin reaction for estimating total lipid. J. Clin. Chem. 18: 199-202.

36. Koch, HP. And Loffler, E. (1985): Influence of silymarin and some flavonoids on lipid peroxidation in human platelets. Methods and Experimental Findings in Clinical Pharmacology, 7: 13-18.

37. Krishnakantha, T. P. and Lokesh, B. R. (1993): Scavenging of superoxide anions by spice principles. Indian J. Biochem. Biophys., 30: 133-134.

38. Letteron, P.; Labbe, G. ; Degott, C. ; Berson, A. ; Fromenty, B.; Delafarge,M. ; Larrey, D. and Pessayre, D. (1990): Mechanism for protective effects of silymarin against carbon tetrachloride induced lipid peroxidation and hepatotoxicity in mice: Evidence that silymarin acts both an inhibitor of metabolic activation and as a chain-breaking antioxidant. Biochem. Pharmacol., 39: 2077-2034.

39. Lii,C. K.; Ko, Y. J. ; Chiang, M. T.; Sung, W. C. and Hen, H. W. (1998): Effect of dietary vitamin $\mathrm{E}$ on antioxidant status and antioxidant enzyme activities in Spraguedawley rats. Nutr. Cancer., 32: 95-100.

40. McCay, P.; Lai, E.; Poyer, J.; Dubose, C. and Janzen, E. (1984): Oxygen and carbon-centered free radical formation during carbon tetrachloride metabolism: 
observation of lipid radical in vivo and vitro. J. Biol. Chem., 259: 2135-2143.

41. Moss, D. W. (1997): Physiochemical and pathophysiological factors in the release of membrane-bound alkaline phosphatase from cells. Clin. Chim. Acta, 257:133-140.

42. Mourelle, M. and Favari, L. (1989) : Silymarin improves metabolism and disposition of asprin in cirrhotic rats. Life Science, 43: 201-207.

43. Muriel, P. and Mourelle, M. (1990): Prevention of silymarin of membrane alterations in acute $\mathrm{CCL}_{4}$-induced liver damage. J. of Applied Toxicology, 10: 275-279.

44. Naziroglu, M.; Cay, M. ;Ustundag, B. ; Aksakal. M. and Yekelev. H. (1999): Protective effects of vitamin $\mathrm{E}$ on carbon tetrachloride-induced liver damage in rats. Cell Biochem. Funct., 17: 253-259.

45. Newall, CA.; Anderson, LA. and Phillipson JD. (1996): Herbal medicines: a guide for health-care professionals. London: Pharmaceutical Press, ix, 296.

46. Niskikimi, M.; Rao, N. A. and Yagii K. (1972): The occurance of superoxide anion in the reaction of reduced phenazine methosulfate and molecular oxygen. Biochem. Biophys. Res. Comm.; 46: 849-854.

47. Ohta. Y.; Kongo, M.; Sasaki, E.; Nishada, K. and Ishigura, I. (2000): Therapeutic effect of melatonin on carbon tetrachlorideinduced acute liver injury in rats. J. Pineal. Res.,28: 119-126.

48. Packer, JE.; Slater, TF. And Willson, RL. (1978): Reaction of the carbon tetra chloride-related peroxy free radical $\left(\mathrm{CCL}_{3} \mathrm{O}_{2}{ }^{-}\right)$with amino acids pulse radiolysis evidence. Life Sci., 23: 2617-2620.

49. Petrelli, G. ; Seipi, G. ; Miligi, L. and Venis, P. (1993) : Solvents in pesticides. J. Environ. Health, 19 : 63-65.

50. Prins, H. K. and Loose, J. A. (1969): Glutathione " chapter 4" in biochemical methods in red cell genetics. Edited by J.J. Yunis. Academic press, N.Y.D. London. P. 126-129.

51. Recknagel, R. O. (1983): A new direction in the study of $\mathrm{CCl} 4$ hepatotoxicity. Life Sci., 33: 401-408.

52. Recknagel, R. O. and Glende, E. A. (1973): Carbon tetrachloride hepatotoxicity: an example of lethal cleavage. Crit. Rev. Toxicol., 2: 263-297.

53. Reddy, A. A. and Lokesh, B. R. (1992): Studies on spice principles as antioxidants in the inhibition of lipid peroxidation of rat liver microsomes. Mol. Cell Biochem., 111: 117-124.
54. Reitman, S. and Frankle, S. (1957): Colourimetric method for determination GPT and GOT. J. Clin. Pathol., 28: 56-63.

55. Riely, C. A.; Cohen and Liberman, M. (1974): Ethane evolution: a new index of lipid peroxidation. Science, 183: 208.

56. Sharma, I.; Gusain, D. and Dixit, V. P. (1996): Hypolipidemic and antiatherosclerotic effects of Zingiber Officinal in cholesterol fed rabbits. Phyto. Res., 10: 517-518.

57. Sherlock,S.and Dooley, J. (1993): Diseases of the liver and biliary system $9^{\text {th }}$ Ed. Oxford: Blackwell Scientific Publications, London P. 17-32.

58. Snedecor, G. W. and Cochran, W. G. (1982): Statistical methods $7^{\text {th }}$ ed. The Stae University Press American, Iowa.

59. Srinivasan, K and Sambaiah, K. (1991): The effect of spices on cholesterol 7 alphahydroxylase activity and on serum and hepatic cholesterol levels in the rat. Int. J. Vitam. Nutr. Res., $61:$ 363-369.

60. Stein, E. A. (1986): Text book of clinical chemistry. N. W. Tietz ed. W. B. Saunders Co. Philadelphia P. 879-886, 1818-1829.

61. Szilard, S.; Szentgyorgyi, D. and Demeter,W. (1988): Protective effect of lgalon in workers exposed to organic solvents. Acta Medica Hungarica, 45: 249-256.

62. Tanaba, M.; Chen, Y.D.; Saito, K. and Kano, Y. (1993): Cholesterol biosynthesis inhibitory comonent from Zingiber Officinal Roscoe. Chem. Pharm. Bull. (Tokyo), 41: 710-713.

63. Tanaka, K. ; Sakal, H.; Hashizume, M. and Hirohata, T. (1998): A long term follow-up study on risk factors for hepatocellular carcinoma among Japanese patients with liver cirrhosis. Jpn. J. Cancer Res., 89: 1241-1250.

64. Tietz, N. W. (1976): Fundamentals of clinical chemistry. $2^{\text {nd }}$ ed. N. W. Tietz ed. Sounders Co. Philadelphia, P. 924-929.

65. Treadway, S. (1998): An Ayurvedic herbal approach to a healthy liver.Clin. Nutr. Insights., 6(16): 1-3.

66. Tribble, D. L.; Aw, T. Y. and Jones, D. P. (1987): The pathophysiological significance of lipid peroxidation in oxidative cell injury. Hepatology, 7(2): 377-387.

67. Velenzuela, A. and Garrido, A. (1994): Biochemical bases of the pharmacological action of the flavonoid silymarin and of its structural isomer silibinin. Biological Research, 27: 105-112.

68. Wellington, K. and Jarvis, B. (2001): Silymarin: a review of its clinical properties in the management of hepatic disorders. BioDrugs, 15: 465-489. 


\section{تقييم تأثير السيليمارين و/ أو الزنجبيل على التسمم الكبدى المستحدث}

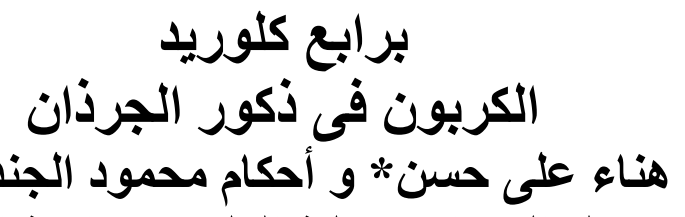

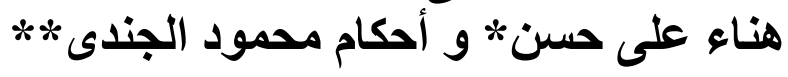

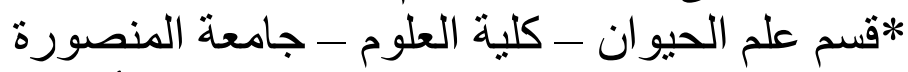

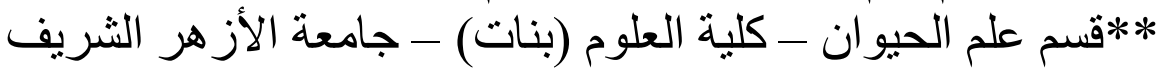

تزداد أمر اض الكبد يومـا بعد يوم بسبب تعرض الانسـان للكيماويات و الملوثات، وسوء استخدام الأدوبة.

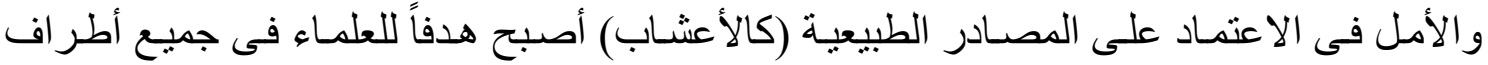

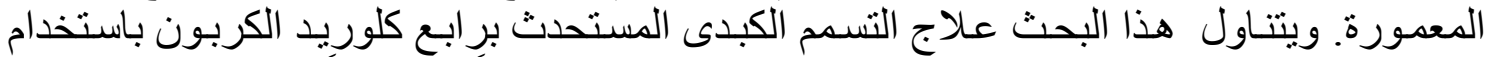

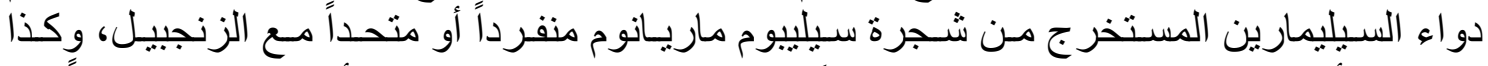

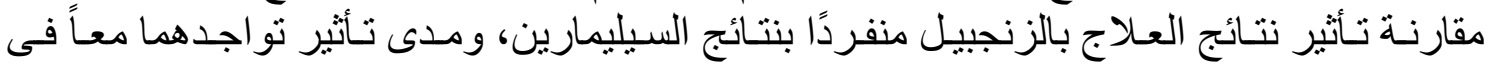

تم معاملة ذكور الجرذان بجر عة حادة من رابع كلوريد الكربون لإحداث التسمم الكبدى وبدأ العلاج

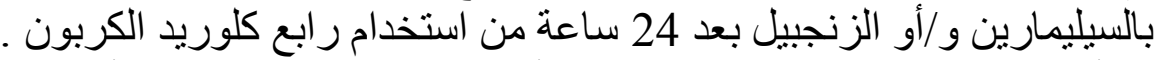

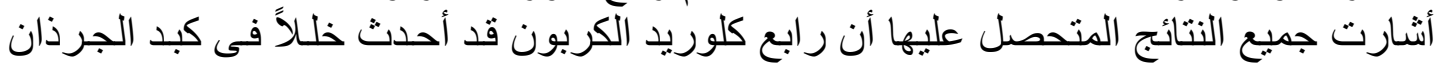

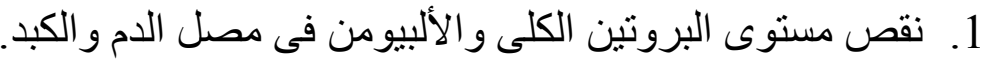

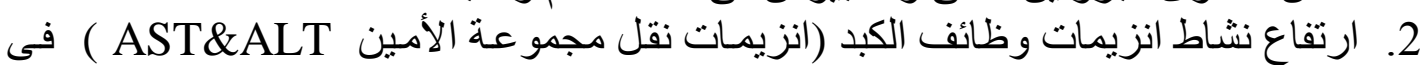
مصل الدم و الكبد.

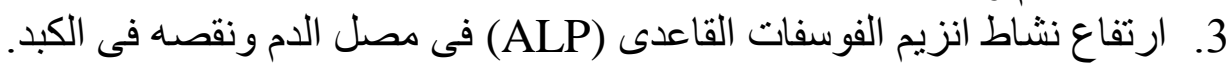

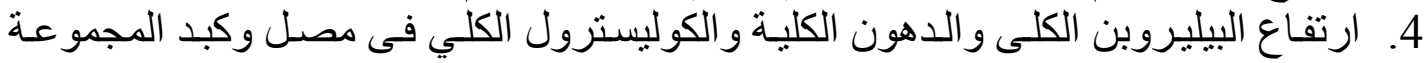
المذكورة.

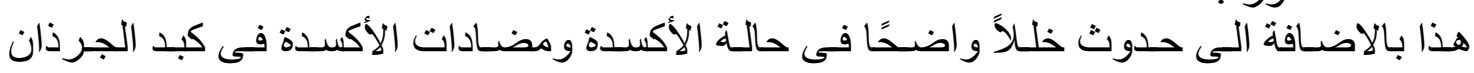

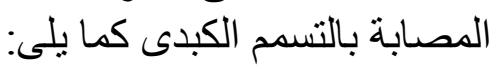
1. ارتفاع مستوى العبىء التأكسدى للاهون في الألى الكبد (TBARS) .

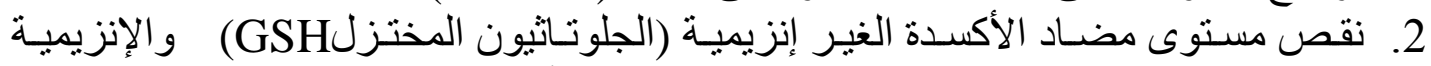

] ولوتاثيون اس تر انسفيريز (GSH-S-T) و السوبر أوكسيد ديسميوتيز و الكاتاليز].

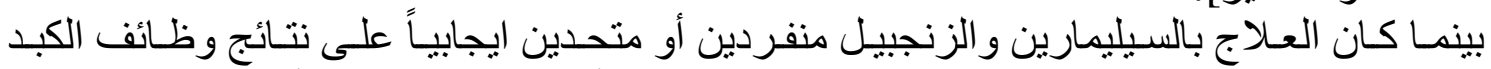

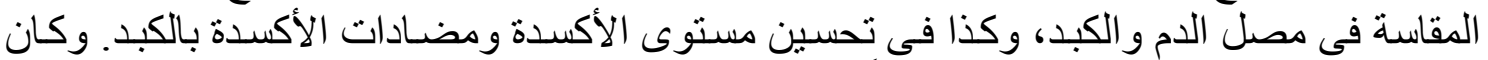
اتحاد السيليمارين و الزنجبيل الأكثر تأثير اً.

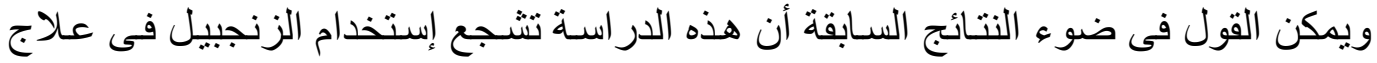
أمر اض الكبد وتوصى بإجر اء المزيد من التجارب عليه و اكثاف المو اد الفعالة بـه. 